\title{
Modeling the Subjectivity in the Target Costing Process: An Experimental Approach Based on the Fuzzy Logic Concepts
}

Fernando Dal-Ri. Federal University of Santa Catarina. Brazil. fernandomurcia@hotmail.com.

José Alonso. Federal University of Santa Catarina. Brazil. jalonso@cse.ufsc.br.

Cesar Duarte. Federal University of Santa Catarina. Brazil. cesarcdm@yahoo.com.br.

\begin{abstract}
The target costing process involves an inherent subjectivity due to the fact that most of the utilized information is both imprecise and ambiguous. The objective of this paper is to propose a methodology based on the fuzzy logic concepts to take into consideration the uncertainty and subjectivity inherent in the Target Costing Process. An example utilizing the production of a tennis racquet has been developed in order to illustrate these fuzzy concepts. The software FuzzyTECH® has been utilized to model the fuzzy target costing process. This research shows evidences that fuzzy logic enables a decision-maker to gain additional insights in the relationship between costs components and products.
\end{abstract}

Key words: Target Costing, Fuzzy Logic, Fuzzy Concepts, Artificial Intelligence, Expert Systems. 


\section{INTRODUCTION}

Many contributions from different areas of scientific knowledge have been brought by specialists to contribute in the resolution of managerial decisions. According to Glautier and Underdown (1994) accounting is being invaded by experts from other areas like computer analysts and production operation specialists which bring to accounting different knowledge and expertise.

The target costing methodology was developed to assist the decision making process involved in making a new product. It evaluates the decision of producing a certain product from its sale price which is established by the market. However the target costing process involves an inherent subjectivity due to the fact that most of the utilized information is imprecise and ambiguous. According to Bayou and Reinstein (1997) since the definitions and measurements of variables in a target costing system involve varying degrees of uncertainty and ambiguity, fuzzy set theory can help managers improve their product design, costs, and targets.

Since the seminal work of Zadeh (1965) called 'Fuzzy Sets', fuzzy logic has become an important tool to handle imprecise information. According to Siegel at al (1998) when the complexity of a system increases, our ability to make precision decision decrease until the point where precision and relevance become mutually exclusive.

In recent times, fuzzy logic has gained some acceptance in accounting and business areas due to its ability to handle uncertainty and vagueness that are not taken into consideration by other binary logic approaches. According to Siegel (1995) "fuzzy logic has been contributing to the development of expert systems technology through the introduction of representational and modeling techniques".

Innumerous researchers have been using fuzzy logic concepts in their business studies. Siegel, Korvin and Omer (1998), Bojadziev and Bojadziev (1997), Siegel, Korvin, Omer and Zebda (1995), among many other researchers that have been applying fuzzy set concepts in accounting areas like: cost allocation, decision making, capital budgeting, risk analysis, asset evaluation, financial analysis, auditing process, etc. 
Deshmukh and Romine (1998) presented a model utilizing fuzzy sets theory for accessing the risk of 'red flags' in management fraud. Syau et al. (2001) used fuzzy numbers in the credit rating of enterprise financial condition. Serguieva and Hunter (2004) developed a model utilizing fuzzy interval methods in investment risk appraisal. Lee, Tzeng and Wang (2005) applied fuzzy set theory to the Cox. Ross and Rubinstein (CRR) model to set up the fuzzy binomial option pricing model (OPM). Pathak and Summers (2005) developed a fuzzy-based algorithm for auditors to red flags in settled insurance claims.

The objective of this study is to propose a model utilizing the concepts of the fuzzy sets theory to handle the uncertainty and subjectivity inherent in the target costing process. The structure of the remainder of the paper is as follows. Section 2 describes some problems encountered in the target costing. Section 3 discusses the fuzzy logic concepts and reviews some recent works in the area. Section 4 presents the construction of the proposed model. Section 5 and 6 presents the final results and conclusions.

\section{TARGET COSTING}

The target costing methodology was first developed in the Japanese automobile industry in order to help the decision of making and selling new products, as well as analyzing product costs and marginal returns. According to Cooper and Kaplan (1998) the target costing essence can be divided in three main parts: (a) allow the market to establish the product sale price (b) subtract the determined product margin required by the company and (c) resulting in the target costing.

Sale Price - Required Return $=$ Target Costing

Some researches have been studying and applying target costing concepts in their works. Dekker and Smith (2003) observed that many companies in Holland utilized managerial accounting techniques that contained target costing concepts that were developed independently of the Japanese context. Lin et al. (2005) described the target costing implementation in a Steel Chinese Company.

Joshi (2001) noted that the implementation of target costing techniques in India has been quite slow, probably due to the country conservative culture. Sulaiman, 
Ahmad and Alwi (2004) showed evidence that target costing techniques have helped companies in Malaysia and India to obtain great results.

Davila and Wouters (2004) as well as Cooper and Slagmulder (2005) advocated against the implementation of target costing techniques in innovating industries and for organizations with have not a consolidated position in their market. The authors of this study agree with this affirmation, as in innovation industries such as software and technology industry, prices do not tend to be set by the market, therefore target costing techniques might not be very helpful.

\section{FUZZY LOGIC}

In binary logic, which was initially formulated by the Greek philosopher Aristotle (384 - 322 A.C.), a proposition is either true or false. This type of logic assumes the states of nature to be well defined events. In accounting and business areas however, the states of nature are vague, and transitions between 'what is' and 'what is not' are not very well defined. According to Zebda (1995) "the development of analytical models that incorporate ambiguity in accounting into decision analysis is needed."

Lofti Zadeh published in 1965 the first paper about fuzzy logic called "Fuzzy Sets". The model was developed to convert subjective values into objective values. A fuzzy set does not have precise and limited boundaries; the difference between belonging and not belonging does not exist, but a degree of pertinence. According to Zebda (1998) fuzzy sets theory is not a decision theory but rather a calculus (a modeling language) where vague humanistic events can be treated in a systematic manner.

The main objective of fuzzy logic is to provide concepts to perform approximate reasoning. Fuzzy logic assumes a degree of pertinence within the 0 to 1 range, which permits the fuzzy set element to be partially true or partially false.

A fuzzy subset can be defined as

$$
\mathrm{A}=\{(\mathrm{x}, \mathrm{Ua}(\mathrm{x}), \mathrm{x} E \mathrm{U}\})
$$


Where: $\mathrm{x}$ is the element and $\mathrm{Ua}(\mathrm{x})$ is the degree of pertinence for each element $\mathrm{x}$ that belongs to the fuzzy set .The pertinence values being 0-1 range.

This fuzzy logic process involves basically three main steps:

1. Fuzzification: conversion of quantitative data into qualitative data in a process also called generalization.

2. Inference: Establishment of inference rules based on relationships between variables.

3. Defuzzification: conversion of qualitative data into quantitative data in a process also called specification.

Fuzzy Logic is becoming an important tool for decision making due to its ability to address imprecise and vague information. Some researchers have been applying the concepts of fuzzy set theory in their papers. Among relevant works utilizing fuzzy logic, one might stand out the works of Zebda (1995) in managerial decision making, Sahin and Dogan (2003) in the relationship between clients and suppliers, and Jiang and Hsu (2003) in the manufacturability and the product life cycle.

In the 'cost segment', examples of relent works are Siegel and Korvin (2001) in cost allocation, Nachtmann and Needy $(2001,2003)$ in activity based costing, Shehab and Abdalla (2002), modeling a cost allocation method, and Smith (2003) in the development of an activity based system (ABC). More specifically in the 'target costing segment', Bayou and Reinstein (1998) examined target costing mechanisms in the automobile industry. According to those authors, fuzzy logic concepts provided a realistic treatment of the fuzzy nature of the measurement of target costing variables.

\section{METHODOLOGY}

Cooper and Slagmulder (2005) proposed joining target costing techniques with other cost techniques. This paper proposes a model using target costing techniques together with fuzzy logic concepts. Like the work of Castellan and Young (2003) we believe that through the use of a simple didactic model using the production of a tennis racquet as an example, complex concepts involved in this work can be 
approached and understood. In order to develop our model, we have utilized the help of specific fuzzy logic software called FuzzyTECH® (www.fuzzytech.com).

The construction of the Fuzzy Target Costing was divided in 2 parts:

4.1. Fuzzification (input data) and Defuzzification (output data) process for the raw material cost, taking into consideration the three components of the tennis racquet raw material: frame, grip and string.

4.2. Fuzzification (input data) and Defuzzification (output data) process for the total cost, taking into consideration the three components of a product cost: raw material, direct labor and indirect costs, generating as a final result the final target costing.

\section{Fuzzy Tennis Racquet Target Costing}

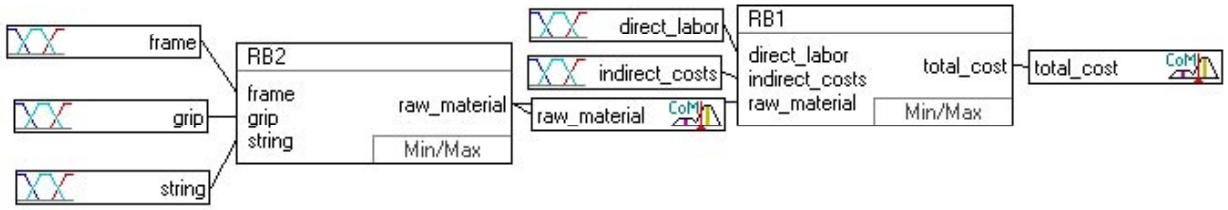

Figure 1: Fuzzy Target Costing Model.

\subsection{Raw Material Costs}

A model utilizing the production of a tennis racquet has been developed in order to illustrate fuzzy logic concepts. One can basically divide a tennis racquet in three main parts:

A. Frame: also know as the "body" of the racquet, is the most expensive part.

B. Grip: part where the player holds the tennis racquet.

C. String: part of the racquet that gets contact with the tennis ball. Figure 2 below illustrates a tennis racquet and its components. 


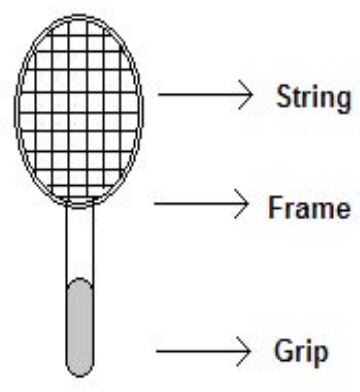

Figure 2: A tennis racquet

Each one of the three parts of the tennis racquet uses one or a combination of raw materials. For instance, the grip can be composed by $80 \%$ rubber and $20 \%$ ladder, or $20 \%$ rubber and $80 \%$ ladder, depending on the racquet model. Table 1 below presents the chosen raw materials that will be used in the proposed fuzzy tennis racquet target cost.

\begin{tabular}{|l|l|l|}
\hline \multirow{4}{*}{ Raw Material } & \multirow{4}{*}{ Frame } & Aluminum \\
\cline { 3 - 3 } & & Graphite \\
\cline { 3 - 3 } & \multirow{2}{*}{ Grip } & Titanium \\
\cline { 3 - 3 } & & Rubber \\
\cline { 2 - 3 } & \multirow{2}{*}{ String } & Leather \\
\cline { 3 - 3 } & & Polyester \\
\cline { 3 - 3 } & & Polyurethane \\
\hline
\end{tabular}

Table 1: Raw Materials.

The raw material components must be converted into the linguistic variables that will form the raw material cost. As one can see on table 1 above, seven linguistic variables were chosen: aluminum, graphite, titanium, ladder, rubber, polyester and polyurethane. Figure 3 below show the fuzzification process for the tennis racquet component "grip". 


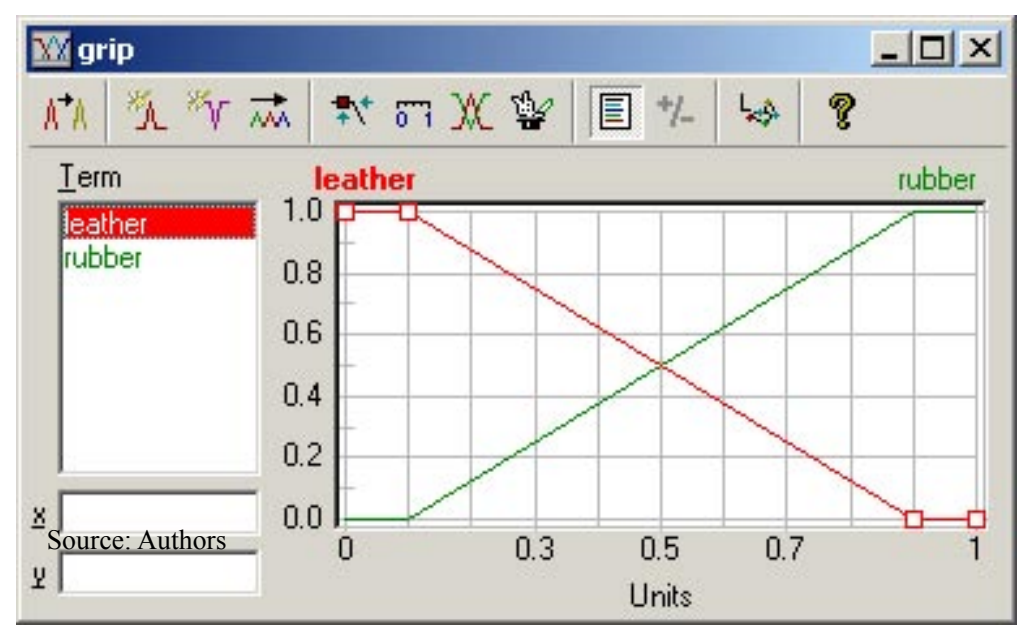

Figure 3: Fuzzification of the tennis racquet component "Grip".

As one can observe in figure 3 , the grip input vale of 0,5 corresponds to a grip composition of $50 \%$ ladder and $50 \%$ rubber. After the fuzzification of all input values, the next step of our model involved the establishment of the inference rules that will result in the defuzzification of the raw material cost (output). Those inference rules represent the manner in which humans make decision, inferring from linguistics premises. For this part of the proposed model, 12 inference rules were created, which can be see in table 2 .

\begin{tabular}{|c|c|c|c|c|}
\hline \multicolumn{3}{|l|}{ IF } & \multicolumn{2}{|c|}{ THEN } \\
\hline Frame & Grip & String & DoS & raw material \\
\hline Aluminum & Leather & Polyester & 1.00 & very_low \\
\hline Aluminum & Leather & Polyurethane & 1.00 & Low \\
\hline Aluminum & Rubber & Polyester & 1.00 & Low \\
\hline Aluminum & Rubber & Polyurethane & 1.00 & medium_low \\
\hline Graphite & Leather & Polyester & 1.00 & medium_low \\
\hline Graphite & Leather & Polyurethane & 1.00 & medium \\
\hline Graphite & Rubber & Polyester & 1.00 & medium \\
\hline Graphite & Rubber & Polyurethane & 1.00 & medium_high \\
\hline Titanium & Leather & Polyester & 1.00 & medium_high \\
\hline Titanium & Leather & Polyurethane & 1.00 & medium_high \\
\hline Titanium & Rubber & Polyester & 1.00 & High \\
\hline Titanium & Rubber & Polyurethane & 1.00 & very_high \\
\hline
\end{tabular}

Table 2: Inference Rules for Raw Material Costs 
The raw material cost will be in the output variable for the second and last part of the proposed model. A total of 7 linguistic output values were adopted in order to better reflect this raw material cost. Those output linguistic values are: very low, low, medium_low, medium, medium_high, high and very high.

\subsection{Product Total Costs}

After obtaining the raw material cost, the next step of our model consisted in the fuzzification of all three cost components: raw material, direct labor and indirect costs. In order to confront those variables, a total of 63 inference rules were created with the help of the software FuzzyTECH®. Those inference rules can be observed in table 3 below.

\begin{tabular}{|c|c|c|c|c|}
\hline \multicolumn{3}{|l|}{ IF } & \multicolumn{2}{|c|}{ THEN } \\
\hline direct_labor & indirect_costs & raw_material & DoS & total_cost \\
\hline Low & Low & very_low & 1.00 & low \\
\hline Low & Low & Low & 1.00 & low \\
\hline Low & Low & medium_low & 1.00 & low \\
\hline Low & Low & Medium & 1.00 & medium_low \\
\hline Low & Low & medium_high & 1.00 & medium_low \\
\hline Low & Low & High & 1.00 & medium_low \\
\hline Low & Low & very_high & 1.00 & medium \\
\hline Low & Medium & very_low & 1.00 & low \\
\hline Low & Medium & Low & 1.00 & medium_low \\
\hline Low & Medium & medium_low & 1.00 & medium_low \\
\hline Low & Medium & Medium & 1.00 & medium_low \\
\hline Low & Medium & medium_high & 1.00 & medium \\
\hline Low & Medium & High & 1.00 & medium \\
\hline Low & Medium & very_high & 1.00 & medium \\
\hline Low & High & very_low & 1.00 & medium_low \\
\hline Low & High & Low & 1.00 & medium_low \\
\hline Low & High & medium_low & 1.00 & medium \\
\hline Low & High & Medium & 1.00 & medium \\
\hline Low & High & medium_high & 1.00 & medium \\
\hline Low & High & High & 1.00 & medium_high \\
\hline Low & High & very_high & 1.00 & medium_high \\
\hline Medium & Low & very_low & 1.00 & low \\
\hline Medium & Low & Low & 1.00 & medium_low \\
\hline
\end{tabular}




\begin{tabular}{|c|c|c|c|c|}
\hline \multicolumn{3}{|l|}{ IF } & \multicolumn{2}{|c|}{ THEN } \\
\hline Medium & Low & medium_low & 1.00 & medium_low \\
\hline Medium & Low & Medium & 1.00 & medium_low \\
\hline Medium & Low & medium high & 1.00 & medium \\
\hline Medium & Low & High & 1.00 & medium \\
\hline Medium & Low & very_high & 1.00 & medium \\
\hline Medium & medium & very_low & 1.00 & medium_low \\
\hline Medium & medium & Low & 1.00 & medium_low \\
\hline Medium & medium & medium_low & 1.00 & medium \\
\hline Medium & medium & Medium & 1.00 & medium \\
\hline Medium & medium & medium_high & 1.00 & medium \\
\hline Medium & medium & High & 1.00 & medium_high \\
\hline Medium & medium & very_high & 1.00 & medium_high \\
\hline Medium & High & very_low & 1.00 & medium \\
\hline Medium & High & Low & 1.00 & medium \\
\hline Medium & High & medium_low & 1.00 & medium \\
\hline Medium & High & Medium & 1.00 & medium_high \\
\hline Medium & High & medium_high & 1.00 & medium_high \\
\hline Medium & High & High & 1.00 & medium_high \\
\hline Medium & High & very_high & 1.00 & high \\
\hline High & Low & very_low & 1.00 & medium_low \\
\hline High & Low & Low & 1.00 & medium_low \\
\hline High & Low & medium_low & 1.00 & medium \\
\hline High & Low & Medium & 1.00 & medium \\
\hline High & Low & medium_high & 1.00 & medium \\
\hline High & Low & High & 1.00 & medium_high \\
\hline High & Low & very_high & 1.00 & medium_high \\
\hline High & medium & very_low & 1.00 & medium \\
\hline High & medium & Low & 1.00 & medium \\
\hline High & medium & medium_low & 1.00 & medium \\
\hline High & medium & Medium & 1.00 & medium_high \\
\hline High & medium & medium_high & 1.00 & medium_high \\
\hline High & medium & High & 1.00 & medium_high \\
\hline High & medium & very_high & 1.00 & high \\
\hline High & High & very_low & 1.00 & medium \\
\hline High & High & Low & 1.00 & medium_high \\
\hline High & High & medium_low & 1.00 & medium_high \\
\hline High & High & Medium & 1.00 & medium_high \\
\hline High & High & medium high & 1.00 & high \\
\hline
\end{tabular}




\begin{tabular}{|l|l|l|l|l|}
\hline \multicolumn{2}{|l|}{ IF } & \multicolumn{2}{l|}{ THEN } \\
\hline High & High & High & 1.00 & high \\
\hline High & High & very_high & 1.00 & high \\
\hline
\end{tabular}

Table 3: Inference rules for product total cost

The output of the proposed "fuzzy logic target costing model" will be denominated "cost of the product". The linguistic output values adopted were: low, medium_low, medium, medium_high and high. Figure 4 below illustrates those linguistic output values.

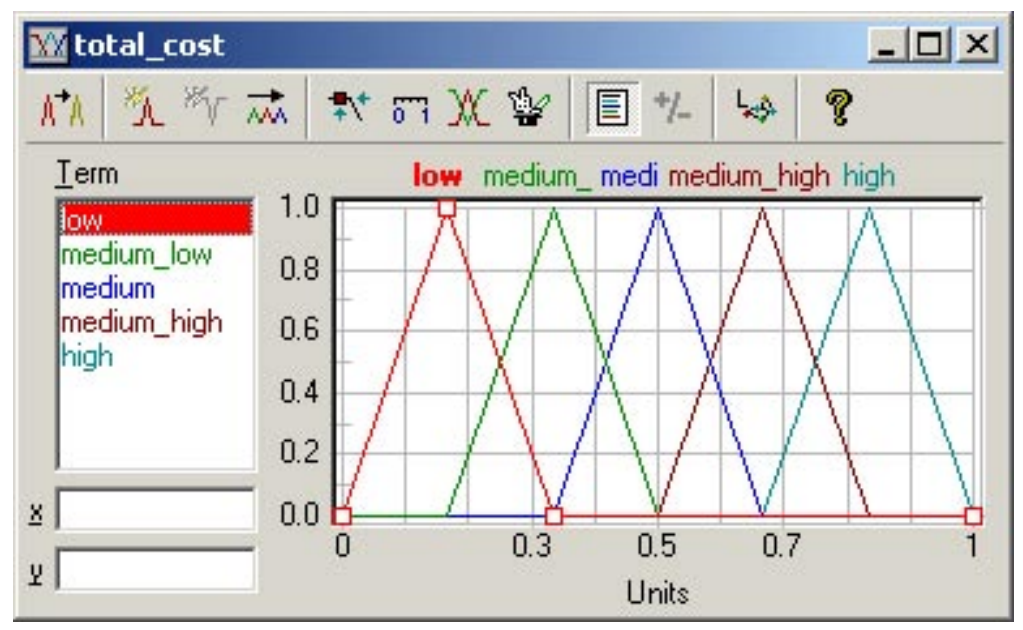

Figure 4: Output Linguistic Values for the Product Total Cost.

Finally, those output linguistic values must be converted in numerical variables. The defuzzification method used in this stage is called "Center of Area Method". The results of the defuzzification process generated by the fuzzy logic model will be called the 'product total costs', which will be utilized to make the decision related to producing the new racquet.

\section{RESULTS}

In order to illustrate our model, we have defined the characteristics of three tennis racquets based on the defined variables of table 1 . We have also established that the maximum acceptable cost to produce a tennis racquet would be $\$ 500$ dollars which would correspond to lunit in the deffuzzication process. 
Based on the discussion proposed by Bayou e Reinstein (1997), instead of establishing the same target costing for all three racquets, we have decided to harmonize the target costing analysis with an additional cost analysis, since the quality and price of all three racquets is quite different. In order to meet this objective, this paper presents three different sale prices determined by the market. Table 3 below presents all the specifications for racquets " $A$ ", " $B$ " and " $C$ ", as well as the sale prices and the expected volume sale.

\begin{tabular}{|l|l|l|l|}
\hline Raw Material & Racquet “A" & Racquet “B” & Racquet C" \\
\hline Frame & Titanium & Aluminum & Graphite \\
\hline Grip & Ladder & Rubber & Ladder \\
\hline String & Polyurethane & Polyester & Polyurethane \\
\hline Direct Material & Low & High & Medium \\
\hline Indirect Costs & High & Medium & Low \\
\hline Sale Price & $\$ 700$ dollars & $\$ 500$ dollars & $\$ 550$ dollars \\
\hline Sale Volume & 750 units & 1500 units & 1100 units \\
\hline
\end{tabular}

Table 3: Racquets Specifications

For the presentation of the proposed Fuzzy Targeting Cost Model, only three products (tennis racquets) were used in order to facilitate the comprehension of these new concepts. However, fuzzy logic concepts when adapted in a real organization scenario, allow the use of various products and innumerous variables. Figures, 5 and 6 illustrate the defuzzification process by the FUZZYTECH software for tennis racquet "A".

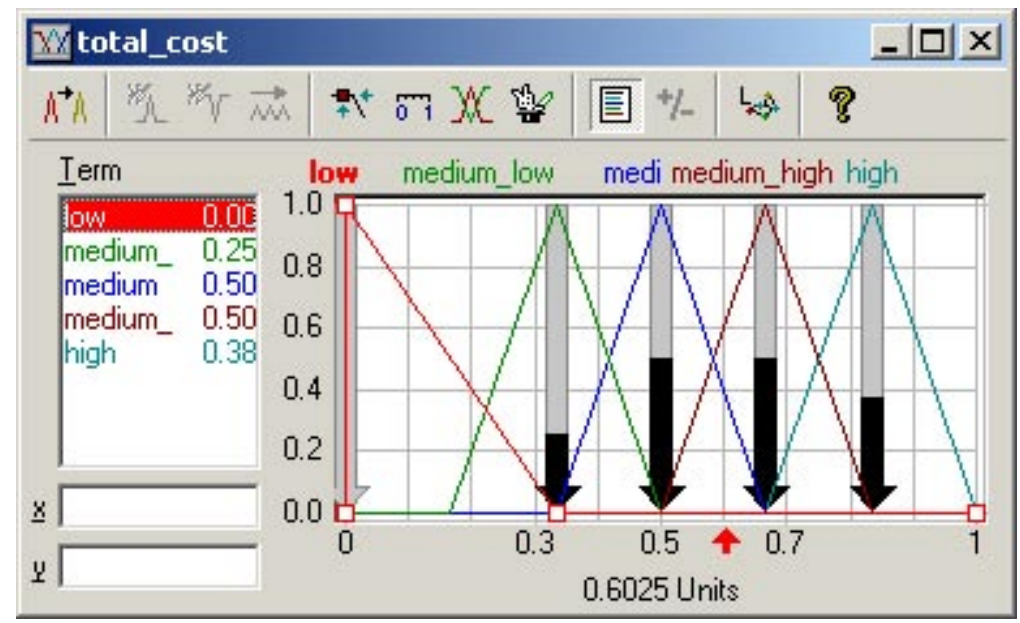

Figure 5: Defuzzification process for racquet "A". 


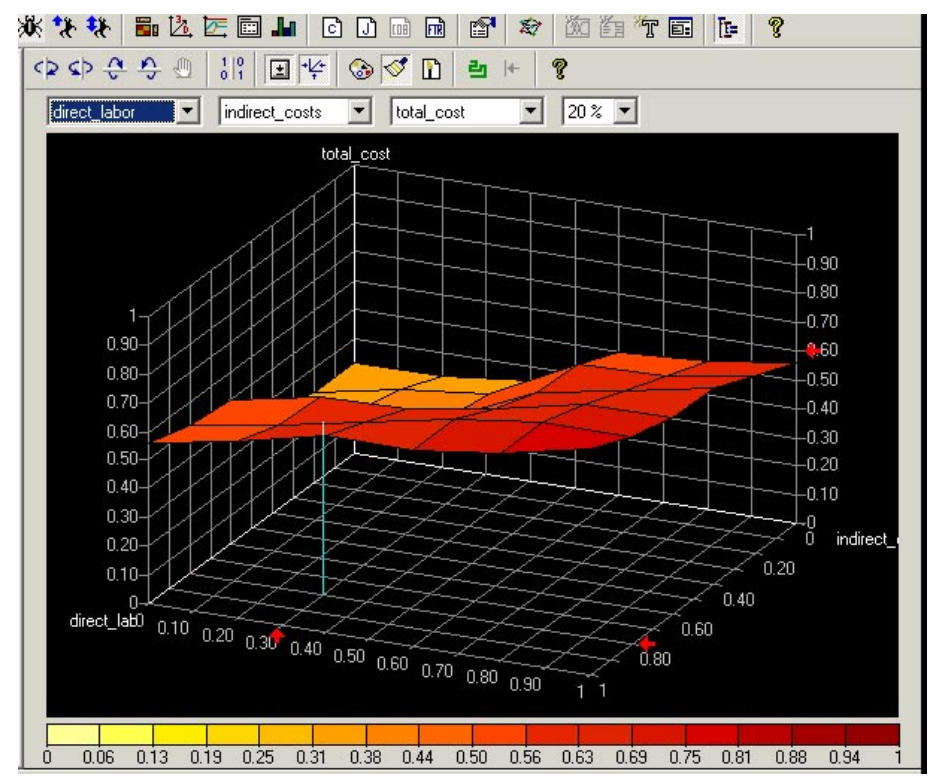

Figure 6: 3D Vision of the defuzzification for racquet "A".

As one can observe in figure 5 e 6 above, the defuzzification process of tennis racquet "A", composed by a titanium frame, a ladder grip and a polyurethane string resulted in a cost of 0.6025 units. Multiplying this values by 500 (specified output value, which corresponds to 1 defuzzification unit) we arrive in a final cost of $\$ 301,25$ dollars. Figure 7 below illustrates the defuzzification for tennis racquet " $\mathrm{B}$ ".

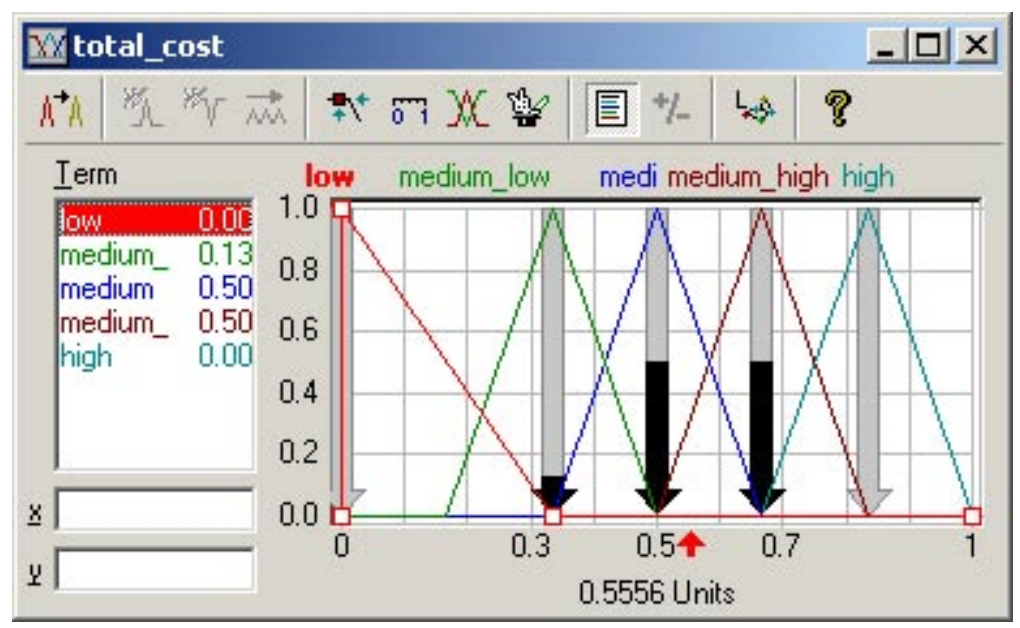

Figure 7: Defuzzification process for racquet "B". 
The defuzzification process of racquet " $\mathrm{B}$ ", which is composed by a aluminum frame, a rubber grip and a polyester string, resulted in a cost of 0.5556 units an $\$ 277,80$ dollars. Although racquet " $\mathrm{B}$ " direct labor cost was higher than racquet "A", racquet "B" presented a lower total cost due to a less expensive raw material (aluminum frame). Figures 8 e 9 below illustrates the defuzzification for tennis racquet " $\mathrm{C}$ ".

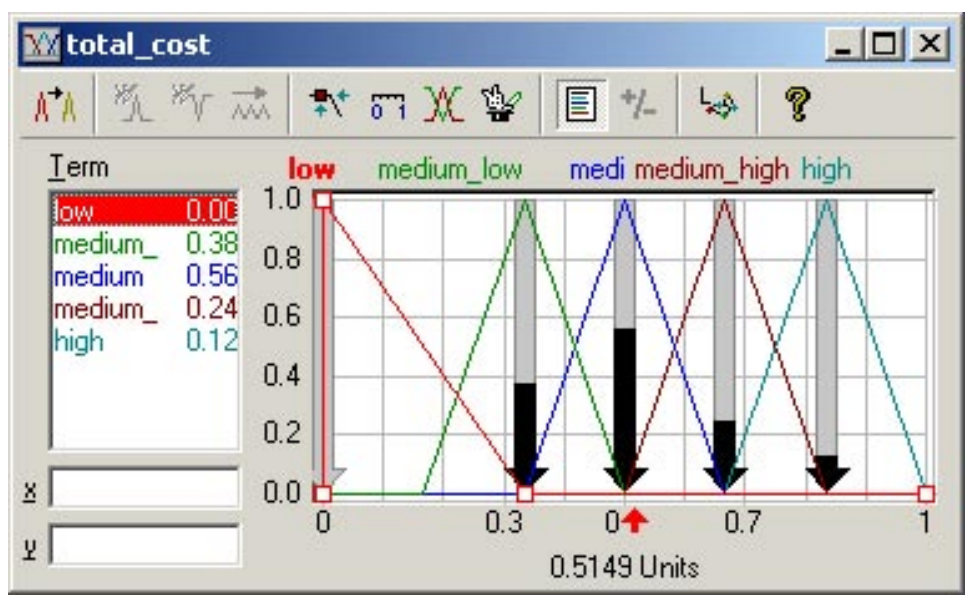

Figure 8: Defuzzification process for racquet "C"

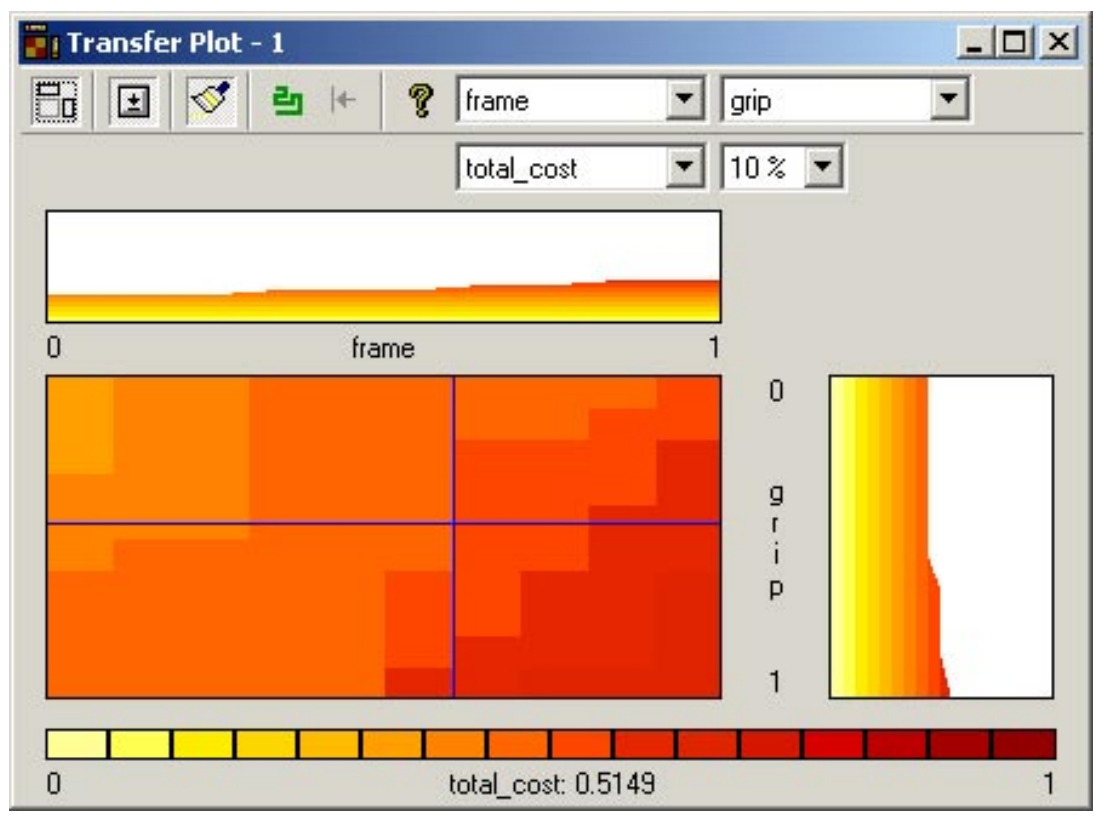

Figure 9: Different view of the Defuzzification process 
Racquet "C" defuzzification process resulted in ca total cost of 0.5149 units and $\$ 257,45$ dollars. Although racquet " $C$ " presented the lowest cost among all three models, and the first option would be to produce it, and discard the other two models, one needs to confront cost information as well as sale price and volume sale. Table 4 below presents a profit, cost, and volume analysis.

\begin{tabular}{|l|l|l|l|}
\hline & Racquet “A” & Racquet” B” & Racquet “C” \\
\hline Sale Price & $\$ 700$ & $\$ 500$ & $\$ 550$ \\
\hline Unit Cost & $\$ 301,25$ & $\$ 277,80$ & $\$ 257,45$ \\
\hline Unit Profit & $\$ 398,75$ & $\$ 222,20$ & $\$ 292,55$ \\
\hline Sale Volume ( units) & 750 & 1500 & 1100 \\
\hline Total Profit & $\$ 299.063$ & $\$ 333.300$ & $\$ 321.805$ \\
\hline
\end{tabular}

Table 4: Profit, Cost and Volume Analysis.

As one can observe in table 4 above, racquet "A" presents the largest profit (margin) by unit. However, when the sales volume is taken into consideration, racquet "B" presents the largest total profit. Those affirmations are only valid if one assumes that other variables as marketing/ administrative expenses, sales expenses and vendor's commission are constant for the three racquets models. One also must assume that the volume sold will be collected, and uncollectible accounts will not affect this decision process. Table 5 below illustrates the final results of the proposed fuzzy target costing model.

\begin{tabular}{|l|l|l|l|}
\hline & Racquet “A" & Racquet "B” & Racquet "C" \\
\hline Unit Cost & $\$ 301,25(3)$ & $\$ 277,80(2)$ & $\$ 257,45(1)$ \\
\hline Unit Profit & $\$ 398,75(1)$ & $\$ 172,20(3)$ & $\$ 292,55(2)$ \\
\hline Total Profit & $\$ 299.063(3)$ & $\$ 333.300(1)$ & $\$ 321.805(2)$ \\
\hline
\end{tabular}

Table 5: Final Results

From table 5 above, one can admit that:

- Racquet "C" presents the lowest unit cost among the three options.

- Racquet "B" presents the highest unit profit (margin) among the three options.

- Racquet "C" presents the highest total profit (margin) among the three options. 


\section{CONCLUSION}

There are many opportunities for the use of fuzzy logic in accounting, auditing, finance and business due to the fact that those areas contain a great deal of ambiguity and vagueness that many times are not taken into consideration in the traditional models based on binary logic.

The objective of this paper was to propose a methodology based on fuzzy logic concepts to Target Costing process Fuzzy Logic concepts were considered helpful due to the fact this complexity involved in the target costing process which involves a great deal of vagueness and uncertainty.

The goal of this research is not to provide the "optimum solution" for the decision maker. This paper only proposes to show an alternative to conventional methodologies based on binary logic. In this sense fuzzy logic can be considered a helpful tool to handle the subjectivity and the uncertainty inherent in the complex process of organization's decision making, as it propose solutions that can model the human decision processing

Finally, one must note that the methodology presented in this paper focused in a didactic model with only three products (tennis racquets) in order to illustrate these new concepts. Although that does not mean that this fuzzy model only can be applied to simple cost process. It is suggested that in future researches the presented methodology can and should be applied to more complex cases involving a great number products, costs, prices and other variables.

\section{REFERENCES}

BAYOU, M. E.; REINSTEIN, A. (1997): "Formula for success: target costing for cost-plus pricing companies", Journal of Cost Management, p. 30-34, sep/oct.

BOJADZIEV, G.; BOJADZIEV, M. (1997): Fuzzy logic for business, finance and management. World Scientific. Singapore.

CASTELLANO, J. F.; YOUNG, S. (2003): "Speed Splasher: an interactive, team-based target costing exercise", Journal of Accounting Education, vol. 21, p. 149-155. 
COOLEY, J.; HICKS, J. (1985): "A fuzzy set Approach to Aggregating Internal Control Judgments", Management Science, vol. (29), 3, p. 317-334.

COOPER, R. (1990): "Implementing an Activity Based Costing System", Journal of Cost Management, p. 33-42, spring.

COOPER, R. (1989): "The rise of Activity Based Costing-Part four: What do Activity Based Cost Systems Look like?", Journal of Cost Management, vol. 3, n. 1, p. 38-49.

COOPER, R.; KAPLAN, R. (1988): "How cost accounting distorts product costs", Management Accounting, vol. 69, n. 10, p. 20-27.

COOPER, R.; KAPLAN, R. (1998): "The promise and peril of integrated cost systems", Harvard Business Review, vol. 76, n. 4, p. 109-119.

COOPER, R.; KAPLAN, R. S. (1998): The design of cost management systems: text, cases, and readings. Prentice Hall. Upper Saddle River, New Jersey.

DAVILA, A.; WOUTERS, M. (2004): "Designing cost-competitive technology products through cost management”, Accounting Horizons, vol. 18, n. 1, p. 1326, mar.

DEKKER, H.; SMIDT, P. (2003): "A survey of adoption and use of target costing in Dutch firms", International Journal of Production Economics, vol. 84, p. 293305.

DESHMUKH, A.; ROMINE, J. (1998); "Assessing the Risk of Management Fraud Using Red Flags: A Fuzzy Number Based Spreadsheet Approach”, Journal of Accounting and Computers, vol. (4), 3, pp. 5-15.

FRIEDLOB, G. T.; SCHLEIFER, L. F. (1999): "Fuzzy Logic: Application for auditing risk and Uncertainty", Managerial Auditing Journal, vol. (14), 3, pp. 33.

GLAUTIER, M.; UNDERDOWN, B. (1994): Accounting Theory and Practice, vol. 5. Pitmam Publishing. 
HARRISON, D.; SULLIVAN, W. (1996): “Activity-Based Accounting for improved product Costing", Engineering Valuation and Cost Analysis, vol. 1, $\mathrm{n}$. 1, p. 55-64.

HORNGREN, C.; FOSTER, G.; DATAR, S. (1997): Cost Accounting: A managerial emphasis. Prentice Hall. Upper Saddle River, New Jersey.

HUSSEIN, M.; TAM, K. (2004): "Pilgrims Manufacturing, Inc: Activity-Based Costing versus Volume-Based Costing", Issues in Accounting Education, vol. 19, n. 2, p. 539-553.

JOSHI, P. L. (2001): "The international diffusion of new management accounting practices: the case of India", Journal of International Accounting Auditing \& Taxation, vol. 10, p. 85-109.

JIANG, B.; HSU, C. (2003); "Development of a fuzzy decision model for manufacturing”, Journal of Intelligent Manufacturing, vol. 14, p. 169-181.

JONES, T.; DUGDALE, D. (2002): "The ABC bandwagon and the juggernaut of modernity", Accounting Organizations and Society, vol. 27, p. 121-163.

KAPLAN, R.; JOHNSON, T. (1993): Contabilidade Gerencial: a restauração da relevância da contabilidade nas empresas. Campus, Rio de Janeiro.

KIM, K.; HAN, I. (2003): "Application of a hybrid genetic algorithm and neural network approach in activity based costing", Expert Systems with Applications, vol. 24, p. 73-77.

KANEKO, T. (1996): "Building a financial diagnosis system based on fuzzy logic production system”, Computers Ind. Engineering, vol. 31, 3/4.

KORVIN, A.; SIEGEL, P.; STRAWSER, J. (1998): “Application of control system to cost variance analysis", Managerial Finance, vol. 3, p. 18-39.

KORVIN, A.; SIEGEL, P.; AGRAWAL, S. (1998): "Application of fuzzy sets to cost allocation", Applications of fuzzy sets and the theory of evidence to accounting, II, vol. 7, p. 55-71, Jai Press, London. 
LEE,; TZENG, WANG. (2005) "A fuzzy set approach for generalized CRR model: an empirical analysis of S\&P 500 index options" Review of Quantitative Finance and Accounting. Vol 25, n.3, p. 255-275.

LIN, T. W., (2005): “Target costing and incentive compensation", Cost Management, vol. 19, n. 2, p. 29-42, mar/apr.

PATHAK; VIDYARTHI; SUMMERS. (2005) "A fuzzy- based algorithm for auditors to detect elements of fraud in sttled insurance claims." Managerial Auditing Journal. Vol. 20, n.6, p.632-644.

NAGASAWA, S. (1997): "Application of fuzzy theory to value engineering", Computers Ind. Engineering, vol. 33, n. 3-4, p. 565-568, Great Britain.

NATCHTMANN, H.; NEEDY, K. L. (2001): "Fuzzy Activity Based Costing: A methodology for handling uncertainty in Activity Based Costing Systems", The Engineering Economist, vol. 46, n. 4, p. 245-273.

NATCHTMANN, H.; NEEDY, K. L. (2003): "Methods for handling uncertainty in Activity Based Costing Systems", The Engineering Economist, vol. 48, n. 3, p. 259-282.

SAHIN, U.; DOGAN, I. (2003): "Supplier selection using activity based costing and fuzzy present-worth techniques", Logistics Information Management, vol. 16, p. 420-426.

SERGUIEVA, A.; HUNTER, J. (2004): "Fuzzy interval methods in investment risk appraisal”, Fuzzy Sets and Systems, vol. 142. p. 443-466.

SHEHAB, E.; ABDALLA, H. (2002): "Intelligent Knowledge based system for product cost modeling", Advanced Manufacturing Technology, vol. 19, p. 49-65.

SIEGEL, P. H. (1998): Studies in Managerial and Financial Accounting: Applications of fuzzy sets and the theory of evidence to accounting, II. vol. 7. Jai Press, London.

SIEGEL, P. H.; KORVIN, A.; OMER, K. (1995): Studies in Managerial and Financial Accounting: Applications of fuzzy sets and the theory of evidence to accounting. vol. 3. Jai Press, London. 
SMITH, K. (2003): "Developing, marketing, distributing, and supporting, and activity based costing decision support system for Schrader Bellows", Issues in Accounting Education, vol. 18, n. 2, p. 175-189.

STEINBART, P. (1987): “The construction of a ruled-based expert system as a method for studying materiality judgments", The Accounting Review, n. 1, p. 97116 , jan.

SULAIMAN, M.; AHMAD, N. N. N.; ALWI, N. (2004): "Management acconting practices in selected Asian countries", Managerial Auditing Journal, vol. 19, n. 4, p. 493-508.

SYAU, Y. (2001): "Fuzzy numbers in the credit rating of enterprise financial condition", Review of Quantitative Finance and Accounting, vol. (17), 35.

TING, P. D. (1999): "Product and process cost estimation with fuzzy multi-attribute utility theory", The Engineering Economist, vol. 44, n. 4, p. 303-331.

ZADEH, L. (2004): "A note on web intelligence, world knowledge and Fuzzy logic", Data \& Knowledge Engineering, vol. 50, p. 291-304.

ZEBDA, A. (1998): “The problem of ambiguity and the use of fuzzy set theory in accounting: a perspective and opportunities for research", Applications of fuzzy sets and the theory of evidence to accounting, II, vol. 7, p. 20-33, Jai Press, London.

ZEBDA, A. (1987): "The choice of management Accounting normative Models: A synthesis", Advances in Accounting, vol. 5, p. 73-98.

ZEBDA, A. (1984): "The investigation of cost variances: A fuzzy set theory approach", Decision Sciences, vol. (15), 3, p. 359-389. 